\title{
Anxiety Level of An Indonesian EFL Student in A Public peaking Class: A Narrative Inquiry
}

\author{
Nur Mahmudi and Mirjam Anugerahwati \\ Graduate Program in ELT, Universitas Islam Malang, Malang, Indonesia
}

\begin{abstract}
Although many studies have been done to uncover speaking anxiety in EFL contexts, very little attention is directed to capturing EFL students' speaking anxiety using narrative study as the research design. To fill the gap, the present study was designed to explore anxiety level of Indonesian EFL students in public speaking class and how the participant deal with his anxiety. This research used a narrative inquiry as the design. Data were collected through online interviewing. Data analysis followed Clandinin and Cain's (2008) three-dimensional space of narrative inquiry. Findings revealed three kinds of anxiety experienced by the students in learning speaking, namely trait anxiety, situational-specific anxiety, and state anxiety Macintyre and Gardner (1991). Furthermore, the causes of speaking anxiety were communication apprehension, test anxiety, and fear of negative evaluation (Horwitz, Horwitz \& Cope, 1986). This paper ends with suggestions form future research investigation.
\end{abstract}

\section{ARTICLE HISTORY}

Received 15 April 2021

Accepted 17 June 2021

Published 04 July 2021

KEYWORDS:

Anxiety, public speaking, EFL students

\section{Introduction}

In a globalized world, English is learned by people across the globe, and for education, this language has been the most important tool for communication globally. However, formal educations have been criticized for not facilitating the learning of English adequately for the students. Such phenomenon indicates that school-based English instruction is likely to be ineffective, as many secondary students lack the capacity to communicate effectively in English (Cahyono \& Widiaty, 2011). As a result, many students enroll in English classes outside of school. An English course is is preferred to assist students who require further teaching and supervision in order to understand the language.

In the context of English as a foreign language (EFL), English speaking can be extremely daunting for students, moreover in a public area. Oftentimes, English students encountered anxiety in the English-speaking practice. Anxiety is an emotional disorder that is characterized by deep and viable feelings of fear or worry. Something that makes the person feels anxious, such as when speaking to the public, taking the test, face interview, etc. Anxiety comes naturally. It has happened to everyone at some point in their lives. Anxiety is now considered a normal aspect of life. Anxiety is a state of mind marked by worry and apprehension over what could occur, both in terms of the immediate situation and strange events. The description of anxiety is feelings of distress and discomfort, and chaotic thought with much regret. This is very influential on the body, until the body feels shivering; causing much sweat, beating the heart quickly, nausea in the stomach, weakening of the body, decreased productivity capacity, until many humans escaped the imagination as a form of temporary therapy. Anxiety is a widespread sensation of fear or lack of self-confidence with no defined source or form.

Many studies have been conducted to investigate students' anxiety in public speaking classes. Recent research by Aripin, Noorezam, and Rahmat (2020) reveal that although speaking 
anxiety is one of the most visible concerns in the language classroom, determining or identifying the existence of anxiety during an oral presentation by simply glancing at the uttered words is challenging. As a result, it is thought that analyzing kinesics' physical movements, face expressions, hand and body movements can offer important information concerning speaking anxiety. Dincer, Ozcelik, Ozer, and Bahcecik (2020) conveyed that public speaking anxiety in a group surveys ranged from $21 \%$ to $33 \%$, indicating that public speaking is a costly and disabling fear. In both university and community samples, public speaking has been identified as the single most dreaded situation. (Bartholomay \& Houlihan, 2016) reveal that Anxiety problems may have a number of detrimental consequences. Anxiety about social situations, especially public speaking, may have a negative impact on someone job prospects. According to Theophillia (2018), Anxiety is a reaction that occurs when someone is scared of something or some activities. Anxiety causes apprehension and disorder in human's mind, such as anxiety over the negative outcomes that can arise when the students speak in public. Furthermore, anxious making mistakes, anxious about not being able to communicate knowledge effectively and other anxieties that really make them mentally down before.

When a viewed from previous studies, many researchers have been conducted research about anxiety in public speaking, yet they did not discuss more specific and without knowing the participant lived story about the anxiety in public speaking. According to (Bartholomay \& Houlihan, 2016) one in every five persons suffers from public speaking anxiety, which is one of the most common types of anxiety. (Gallegoa, McHugh, Villatte, \& Lappalainen, 2020) reveal that as university students go through their studies and into their jobs, public speaking is a vital talent to master and practice. (Lindner et al., 2018) stated that public speaking anxiety is a frequent problem that may be effectively cured with exposure therapy.

Research on anxiety in public speaking has also been studied by Kelsen (2019) in foreign language (FL) learning scenarios. It was found that personality characteristics and anxiety have been recognized as having an impact. Furthermore, research has shown that personality traits have a part in predicting an individual's proclivity for anxiety. However, few researches have looked at the relationship between personality and anxiety in English as foreign language (EFL) contexts, especially when it comes to giving presentations. Suleimenova (2013) also took a part of this research. He said that anxiety is described as mental discomfort or unease brought on by a dread of danger or catastrophe. Excessive and exaggerated worry over commonplace events is referred to as general anxiety. It's a persistent anxiety that's unreasonable or out of proportion and it takes over and disrupts daily tasks like job, school, relationships, and social activities. According to Cagatay (2015,) learning a foreign language entails both cognitive and emotive characteristics on the side of the students. Anxiety is one of the most commonly encountered issues in the emotive dimensions of the language acquisition process.

The aforementioned studies were carried out on formal schooling. Thus, it is important for researchers to investigate public speaking anxiety in non-formal institution. Moreover, in the pandemic era, it is essential to investigate anxiety level of Indonesian EFL students and explain how the students anticipate their anxiety in a public speaking class. On the other hand, he wants to know the teaching learning process of public speaking class. The researcher uses a narrative inquiry as approaches. The researcher decided using narrative inquiry because he wants to hear how anxiety level of Indonesian EFL students and explain how the student anticipates his anxiety in a public speaking class. The narrative approach refers to (Clandinin $\&$ Caine, 2008) statement which states that narrative inquiry is first and foremost a way of understanding experience. As a result, it is both a view of the phenomena of someone experience and a method for narrative inquiring into experience, allowing for a more in-depth examination of individual perceptions over time and in detail. The researchers take care of location, temporality and sociality from inside a three-dimensional, methodological narrative space for exploration of both the researcher's and the participant's context, starting with a narrative view of experience. In light of the above problems, this study investigated anxiety level of an Indonesian EFL student in a public speaking class. 


\section{Literature Review}

\section{The nature of anxiety}

Anxiety feeling can appear when someone will speak in public because of nervousness. Feelings of anxiety can be seen with signs such as trembling, pallor, producing excessive sweating, nervousness, controlling eyes contact, unstable movement and body language when speaking in public. Anandari (2015) found that embarrassment, unease, and a negative attitude about someone's performance were among the reasons of speaking anxiety among the students in their study;and apprehension of being badly judged by the audience (Irawan, Warni, \& Wijirahayu, 2018); and likewise in Ahmed's (2016) study which indicated that the students were primarily terrified of failing or making mistakes in their speeches, as well as being embarrassed by their classmates. When the students refer to the sign above when giving public speaking, they are anxious. Students who exhibit more of the abovementioned characteristics must help students reduce the sense of anxiety that exists in them before anxiety becomes a serious problem for students. There are two kinds of anxiety Santriza (2018). It was explained as follows:

Table 1. The Kinds of Anxiety

\begin{tabular}{lcl}
\hline No & Anxiety & \multicolumn{1}{c}{ Definition } \\
\hline 1. & Trait Anxiety & Trait anxiety is a kind of anxiety in many ways that a person \\
& & experience. Brown (1994) revealed trait anxiety is a more lasting \\
& anxiety propensity. In this example, a person feels worried all of the \\
& time, even in non-threatening situations. Furthermore, anxiety may \\
& be a person's personality trait. As mentioned by Ormod (2011) \\
& clarified even in non-threatening situations, trait anxiety can arise. \\
\hline 2. State Anxiety & $\begin{array}{l}\text { State anxiety is a type of anxiety that develops when a person accepts } \\
\text { a situation as hazardous, damaging, or threatening to him or her } \\
\text { Spielberg (1992). It suggests that state anxiety is just transient; it } \\
\text { only happens when someone perceives a damaging or unsafe } \\
\text { situation, and it will dissipate after the scary occurrence has passed. }\end{array}$ \\
\hline
\end{tabular}

To understand more about the concept of language anxiety, Macintyre and Gardner (1991) identified three types of anxiety. It was explained as follows:

Table 2. The Kinds of Anxiety

\begin{tabular}{lll}
\hline \multicolumn{1}{c}{ No } & \multicolumn{1}{c}{ Anxiety } & \multicolumn{1}{c}{ Definition } \\
\hline 1. & $\begin{array}{l}\text { Trait anxiety } \\
\text { (a personality } \\
\text { trait) }\end{array}$ & $\begin{array}{l}\text { Woodrow (2006) considered trait anxiety is a personality trait that is } \\
\text { relatively consistent. An individual who suffers from this anxiety is } \\
\text { prone to experience anxiety in a range of settings. }\end{array}$ \\
\hline 2. & $\begin{array}{l}\text { State anxiety } \\
\text { (an emotional } \\
\text { state) }\end{array}$ & $\begin{array}{l}\text { State anxiety is a transitory phenomenon that occurs at a certain } \\
\text { time. }\end{array}$ \\
\hline 3. & $\begin{array}{l}\text { Situation } \\
\text { specific } \\
\text { anxiety } \\
\text { (anxiety in a } \\
\text { well-defined } \\
\text { situation) }\end{array}$ & $\begin{array}{l}\text { Situation specific anxiety is a symptom that occurs only in certain } \\
\text { settings. }\end{array}$ \\
\hline
\end{tabular}

Anxiety of this nature is induced by a variety of factors. Anxiety is a natural emotion-related behavior that might be seen as "healthy" Felman (2020). In Pakistan, approximately $75 \%$ of students said they were afraid of public speaking Raja (2017). It's understandable that public speaking anxiety or fear of public speaking affects many people (Knight, Johnson, \& Stewart, 2016). It represents a speaker's emotional reaction, which might lead to an awkward scenario while speaking in front of a group. This claim is in line with Liu's (2007) lack of vocabulary, low English proficiency, lack of preparation, lack of practice, fear of making mistakes and being laughed at, fear of losing face, fear of being the center 
of attention, fear of not being able to follow and understand others, inability to express ideas, and the last memory disassociation were among the nine factors that affected students' anxiety.

\section{The anxiety in public speaking}

Anxiety among students is a result of their lack of English class skills, such as vocabulary, grammar, pronunciation, and word use. It will certainly decrease their confidence in speaking English in front of the public, thus reducing their ability to speak in public. In the context of state anxiety, where they only feel nervous when facing English lessons, particularly public speaking, the anxiety faced by students is included. Instead of taking the risk of falling again, students who have suffered failure to speak will opt quietly. They are worried that classmates will laugh at them and eventually reduce their confidence. As mentioned by Lanefeldt (2011), speaking anxiety has a significant effect on a person's self-confidence as they speak up and demonstrate what they know.

In conclusion, anxiety is a serious issue that can endanger students' ability to speak English, especially public speaking. As we all know, public speaking is an essential component in interacting with people. In this situation, by developing an efficient and fun classroom environment, the teacher must be able to support students to feel relaxed and not feel stressed. (Horwitz, Horwitz \& Cope, 1986) revealed that in language learning, there are three types of anxiety. They are communication apprehension, test anxiety, and fear of negative evaluation:

Table 3. Three Types of Anxiety

a. Communicative Apprehension
Communicative apprehension is described as a sensation of shyness as a result of dread affecting one's ability to communicate with others. In this scenario, students who have difficulty speaking in groups have a hard time speaking in a foreign language lesson. In a communicative scenario, students have less control. As a result, it has an impact on their public speaking.

b. Test Anxiety When students are concerned about failing an exam, they develop test anxiety. Since the exam, students who are nervous about testing in a foreign language class might be offered a difficulty test and quizzes. Even students who had done their homework made mistakes on the examination.

c. Fear of Negative Evaluation
Students who are not just anxious when taking a test are said to have a fear of bad assessment. In highly socially evaluative situations, such as job interviews or speaking in a foreign language class, they may feel uneasy.

The causes of students' anxiety can be divided into three categories. First, communicative apprehension happens when students are unable to talk in front of others. Second, test anxiety occurs when the students are concerned about taking an English test. The last, the students experience fear of negative assessment when they are anxiously confronted with a social evaluation situation, such as a job interview or speaking in a foreign language class.

There has been a significant uptick in research into foreign language anxiety, particularly as it relates to speaking abilities. Suleimenova (2013) noted that concerns about communication ability among second or foreign language learners have risen in recent years, leading to increased speaking anxiety. Foreign language learners in his research claimed that they are stressed, frightened, and apprehensive when learning to speak in the target language and that they have a "mental barrier" towards learning the language. Likewise, Karatas et al. (2016) supported Suleimenova (2013) the idea that students in a language course must present themselves orally in front of their peers and engage in group discussions. When communication skills are emphasized in the language classroom, students will be scared to execute such tasks and see them adversely.

As previously said, public speaking anxiety is a significant and complicated issue that a variety of factors may cause and has major implications. In addition, previous research shows that foreign language anxiety is a key factor that influences foreign language learners' performance and acquisition Atas (2015). Moreover, as reviewed, most studies on anxiety in public speaking focused on students in formal school, with little research targeting a non-formal 
school. As a result, two research issues were addressed in this research: (1) How is the anxiety level of Indonesian EFL students in a public speaking class at the English course? (2) How does the student anticipate his anxiety in a public speaking class at the English course?

\section{Method}

This research investigates the anxiety level of Indonesian EFL students in a public speaking class; therefore, it was conducted using qualitative method and narrative inquiry as design. To explore student experiences, it is very suitable to use narrative inquiry. Narrative inquiry is the first and most important way to understand experiences. Over the last few decades, researchers have turned to narrative to understand experiences (Clandinin \& Caine, 2008). In recent research, many researchers haven't used a narrative inquiry approach in investigating and exploring student experiences (Kelsen, 2019; Suleimenova, 2013; Cagatay, 2015). The research above became the researcher's reference for choosing narrative inquiry as an approach or method to explore anxiety in a public speaking class. As Creswell (2012) proposes, as a design, "narrative research" focuses on "studying a single person, acquiring data through the collecting of stories, describing unique experiences, and debating the significance of those experiences for "the individual." John Dewey's theory of experience cited on (Clandinin \& Caine, 2008) provides a foundation for attending experience through Three-dimensional space for narrative inquiry, namely the dimensions of temporary, place and sociality. This threedimensional space of narrative inquiry allows for investigation into the multi-level life experiences of researchers and participants. This place situates and understands the tales told and lived in the greater cultural, social, and institutional narrative. The focus on relationships between the researcher and the participant distinguishes narrative inquiry.

\section{Profile of participant}

The researcher first met Boy (pseudonym, male, 23 years old) in one English course in Pare. He had a big curiosity in English. He desired to continue his study abroad. His junior and senior high school was in Islamic Boarding School based in Paiton, East Java, Indonesia. He studied in Islamic boarding school for many years. Thus, he was good in Arabic. At that time, he had graduated from Islamic Boarding School. He was interested in English so he came to Kampung Inggris Pare to study English. He stayed in Kampung Inggris Pare for many years. He showed how he struggled to study English. The researcher and Boy stayed at the same camp. They met every day and every time. They studied together. He studied diligently.

When he had to speak English in front of many people, Boy was nervous, but his English was adequate. He looked sweaty all over, his hands were trembling and he had no idea to speak. He was speechless. He pushed and challenged himself to have good English and confidence by joining debate competition and speech competition. He also joined international public speaking club. That is Toastmasters. "Toastmasters" is an international public speaking club for those who want to improve their public speaking skills and leadership. Finally, he knew what he should do to be confident. Now his English and confidence are better than before.

At that time, Boy said that he wanted to be teacher in one of English courses in Pare. He shared a lot of his struggle of being teacher in that English course. While he became a teacher in English course, he also continued his study in one of the universities in Kediri, East Java, Indonesia. It means that he never stops to learn. When this research commenced, he has just graduated from the university. Thus, he is in Pare for many years, he starts from being student until being a teacher. He wants to continue his study abroad. He wants to get good score in IELTS. Therefore, in this study, I opt for the subjectivity of meanings from the participant's lived experiences rather than the objectivity of the experiences.

\section{Data collection method}

In this research, data collection was needed to describe the anxiety level of Indonesian EFL students in a public speaking class. In this qualitative research, the researcher used one-on-one interviews. One-on-one interviews are best for interviewing participants who aren't afraid to speak up, who are good at speaking, and who can freely express their opinions (Creswell, 2012). The interview takes place several times, running around 50 to 60 minutes. The researcher and the participant are in the online interview because it is impossible for the researcher to hold face to face interview during covid19 pandemic. The researcher employs an online interview setting with zoom application, WhatsApp chat and voice note. Due to some problems during the interview (such as internet connection and the 
participant activity), the interview was done twice on February 25th and March $13^{\text {th }}, 2021$. The instrument of the interview applied in this study was validated by two experts (Polkinghorne, 2007). (Polkinghorne, 2007) stated that the goal of the validation process is to persuade readers that the evidence supporting the argument is good enough to justify the claim as a foundation for understanding a human activity.

\section{Data analysis}

Organizing enormous volumes of data, transferring it from spoken or written words to tapes files, and deciding whether to analyze data by hand or by computer are all part of the initial data preparation process (Creswell, 2012). The researcher begins to collect the stories and information from the participants into a computer folder for analysis because data organization is very important in qualitative research. The large amount of information collected during the research. The researcher reads many times the interview transcripts and construes the analyzed documents obtained in the data collection. Whenever the researcher reads participant data, it means the researcher is developing a deeper understanding of the information provided by the participants. Agar (1980) also suggested researchers "read the transcript at whole several times. Immerse yourself in the details; try to understand the interview whole before breaking it into parts" (p. 103). Afterward, the researcher constructs a life story of the participant using holistic content presentation. This type of content analysis excludes preliminary categories in a narrative study. After constructing the participant's life story, the researcher begins to analyze the transcript using a three-dimensional space of narrative inquiry: the dimension of time, person-social, and place (Clandinin $\&$ Caine, 2008). Furthermore, the researcher conducts member checking asking for feedback on whether the analyzed data is following what was conveyed by the participant. The researcher also had a conversation with the participant via WhatsApp to clarify any vague sentences in the storied experiences.

\section{Findings}

The findings of this research were explained using Clandinin and Connelly's (2000) narrative frameworks: past, present, and future dimensions of a story. After interviewing the student, the researcher found a variety of problems that were anxiety factors in student.

\section{Past experiences}

The researcher's initial inquiry to the participant's lived experiences was about his personal reasons of learning English and continued with past English achievement and classroom learning. It is very intriguing to see how the participant shared his intrinsic motivation in learning English. It is depicted in the interview.

\section{Excerpt 1 \\ I really loved English since I was second grade or third grade of Elementary School. I remembered that my sister taught me English. I studied with her at home. She asked me to memories some daily words and vocabularies such as days, numbers, animals, fruits and others. She gave me some English songs. Then when I graduated from my elementary school, I went to Islamic boarding school. I studied English there from junior high school to senior high school. Beside that I also stayed in English camp or the common name as English dormitory, so we always spoke English for our daily communication. My dad also helped me. He gave me some games in computer. When I could pass the game, there were English songs that made me really happy.}

When the researcher asked about his past experience of starting to study and love English, Boy shared that he started to study and love English since he was kid, but he felt bored. He almost gave up studying English because he could not speak English well, but he motivated himself to study English.

\section{Excerpt 2}

I was really curious about English when I was kid. I also got experience that learning English for me was so much boring or something kind of I can't stand on it. When I was second grade of junior high school, I almost gave up because I 
couldn't speak English after two years learning so I told to my teacher that I wanted to give up learning English but then I just keep trying again and again up to now. I just kept going on.

Boy encountered some problems associated with his self-competence. Boy shared that he got bad experience to speak English in public when he was in school. He did not want to be center attention. Before he came forward and delivered his speech, he already prepared the speech before, but everything was gone.

\title{
Excerpt 3 \\ I remembered that it was 2010. It was just like opening ceremony or MC. I just did well in the opening "excellency, honorable". In the middle of the speech everything was gone. I couldn't remember anything. I was just silent. My hands were trembling. I was sweaty. My heart beating was so fast. It happened because I was really nervous, worry, and anxiety being center attention of people. I was so scared to speak in public. Actually, I prepared one week. My teacher gave time to memorize but when I was on the stage, I just memorized three sentences. Start from that moment when my teacher asked me to be the next participant for public speaking, I said "I was afraid of being center attention because the audiences looked at me".
}

Boy added an explanation during the interview. He felt anxiety when he had to speak in public.

\begin{abstract}
Excerpt 4
I felt anxiety before I performed. I was really nervous because that was the first time for me to speak in public. I was in first grade of junior high school. I was really trembling, nervous and anxiety. I couldn't handle on it and finally I couldn't remember all the text that I have memorized. Finally, I was blank and I stopped. When my teacher asked me to speak in public, I always said that I didn't want to speak in public. I got used to say that word. For one year I stopped doing public speaking because of really bad, nervous, anxiety and panict. I run to cafeteria to skip that moment. I run to the toilet if my teachers chose me to be the speaker. That was the bad thing happened to me. When the time goes by, I can handle myself how to be more confident and how to control my emotion and stabilize my felling when I speak in public.
\end{abstract}

In the context of anticipating anxiety in public speaking, boy shared that he ever joined debate and public speaking competition to make his confidence better.

\begin{abstract}
Excerpt 5
It was second grade of senior high school. Some universities held English Olympiad. I encouraged myself to participate on that competition. I was lost because the best school in Malang became number one. So in semifinal I had just placed myself in number fourteen. I was really proud of me because it was my first time. When I was in university, I joined debate competition. It was third semester. I got top number three. I also joined public speaking competition when I was forth semester and I got the first one. I also joined news anchor in my university, I got number two. For the international, I joined toastmasters' competition but I didn't get any champion.
\end{abstract}

\section{Present experiences}

The research also inquired participant's lived experiences of studying English in public speaking class. In the interview, Boy shared that He never joined public speaking class before. He learned to speak in public by himself. The first time he joined public speaking class was in Kampung Inggris Pare. Boy shared that: 


\title{
Excerpt 6
}

The first I joined public speaking class. It was in Kampung Inggris Pare. I never joined public speaking class before, I just trained myself, I just encouraged myself to speak in public. I started to speak in public and being center of people 2011 as I told you before. When I was junior high school I didn't become speaker again because I failed. And 2015 I joined public speaking class in Pare.

Boy got experiences and lessons. He contended that the way the teacher in a public speaking class taught and gave feedback. In the interview, Boy shared that:

\begin{abstract}
Excerpt 7
I joined public speaking class. The class was really fun because the teacher gave very detail feedback in every single performance of the students. She gave corrections like performance, language, grammar, title, content. She really gave detail feedback. What I learned on that class was how to make good a speech, and how to make good title, body language, vocal variety, eyes contact and facial expression.
\end{abstract}

Boy added an explanation during the interview:

\begin{abstract}
Excerpt 8
When one student finished delivering the speech, the teacher gave feedback directly. Teacher gave good feedback. She never said bad thing from us. She chose to use good sentence and motivation. The way that she gave feedback was always positive even we made mistakes she never said "your grammar is bad, your English is bad, your pronunciation is bad". She never said that words.
\end{abstract}

Boy also shared that the teacher used media in public speaking class to support the teaching and learning process. The teacher used camcorders and LCD projector. The teacher wanted the student to practice to do public speaking in front of camera. The student should give good eyes contact with the camera. Then the teacher gave an evaluation while watching together the performances that already recorded by the teacher with LCD projector. Boy shared that:

\begin{abstract}
Excerpt 9
The teacher used whiteboard, marker, and camcorders. She used camcorders because she really wanted us to practice to speak on camera. She recorded our performance. The teacher gave really clear and detailed feedback while we watched our performance by LCD projector that was already recorded by her. She said that we should do well on gesture, eyes contact, facial expression, vocal variety, stance, movement and others. The teacher showed us the videos about the best public speaking such as Toastmasters and TED Talk. The teacher also encouraged us by giving some stories, by giving motivational sentence to make us be more confidence so we really believed that we could speak in public.
\end{abstract}

Boy added an explanation during the interview. He describes the process of teaching and learning in a public speaking class.

\section{Excerpt 10}

It was really nice and understandable. It was easy to engaged with the lesson because the teacher explained the lessons very detail like body language, how we could make good the title for the speech, vocal variety, intonation in public speaking. I thought that it was clear enough for the teacher explanation to the students. The English course had five classrooms and one hall for learning English which was facilitated by the owner of the English course with AC, fan, whiteboard, chairs, LCD Projector, laptop and adequate equipments. It really supported me to study. 
Boy was not good on memorizing, so he made some points and practices again and again. He did not care what the people thought. The important thing was that he just wanted to do the best, so he tried to control his mindset. He shared the way he handled and conquered his anxiety.

\title{
Excerpt 11
}

I solved and conquered my anxiety when I spoke in public. I did preparation. I was a kind of person that I was not really good in memorizing because it would make me only focused on that speech. So, I just made some points. I could improve my speech. So, I made some points and I practiced it. When I was on the stage, I just took a deep breath and I enjoyed. I just didn't care what people were going to say about me. "People cared or didn't care" I don't care about it. What I did that it was just practice.

\section{Future expectations}

At the end of the data collection, the researcher inquired about participant's future goals in terms of public speaking anxiety and trained for his future career. This was done to construe the participants' reflections after exploring his past and future lived experiences. The participant agreed that becoming a professional public speaker who could enjoy, relax and having good confidence was vital for the future career. He assumed that someone who had good communication skill, it would help the future career. "If you can tell, you can sell" means that when someone has good communication skill, he has power. Boy in the interview shared that:

\section{Excerpt 12 \\ I tried to handle myself to speak English in public. I built my confidence. Now I really enjoyed when I spoke in public. I believed that public speaking made us easier to get along with others. Public speaking class is really required today because company requires employees who have good skill in communication. And one of skill in communication is public speaking I guess.}

Boy got motivations and suggestions from his teacher in public speaking class to be the best public speaker. In the interview, Boy shared that:

\section{Excerpt 13 \\ Okay, well actually my teacher just said that practice, practice, prepare, practice only that word. I meant that before I performed, I had to prepare and practice. I practiced in front of mirror and in my room because there were no people. Only that, prepare, practice, then perform that was the simple word that I always did.}

Boy shared his best experiences and suggestions for English learners to decrease their anxiety when speaking in public. He also gave the best advice and suggestion for English learner to be good public speaker. He shared it in the interview:

\begin{abstract}
Excerpt 14
When we want to become public speaker, it starts from our mindset because the difficult thing is not only being speaker in public but also the difficult is from mindset, for example how if I make mistake because English is not my language, how if I make mistake in grammar and pronunciation, how if my audiences don't understand what I have delivered then I am useless. So the problem is not only nervous but also delivering language. My suggestion is that change our mindset beside that we need practice. To change our mindset it is not taken in short term. It takes long term. We Just say to ourselves that we can do it and we just believe that people understand us as long as we do good. If we want to be good speaker, we need process, we need long term may some weeks, some months or even years.
\end{abstract}

Boy added an explanation during the interview: 
Excerpt 15

When I am on the stage, I keep myself calm and relax. I will see the audience first to give the interaction. I will see from the right to the left for 10 to 15 second. I take a deep breath and I relax. I start and see the audience eyes. Of course I prepare before I perform and I practice. Well, first thing if we are English learners, don't think that English is hard. Second change our mindset such as when we make mistake don't judge ourselves, never think negative like people will say "ah, your grammar and pronunciation is bad". For sure that you have to do is that you just go on. When you have good communication skill, you can have good carrier. When you want to apply for job, you have to have good communication skill. When you have good communication skill, you have power.

Lastly, Boy contended that his feeling when he became a student and teacher. He became creative and innovative in learning and teaching. It is depicted in the interview with him:

\begin{abstract}
Excerpt 16
When I was as student, I learned many things from teacher. That was the best that I got. I became teacher. It started 2015. At that time I finished my senior high school then my dad asked me to study English in Pare for two months. Then I told to my teacher that I really want to be teacher because I am still postpone to continue my study in university. 2016 I continued my study in one of universities. I got many trainings. The best thing that I got was pre-service English teacher training. When I was six semester, I got golden opportunity from US embassy to study English with them. For two weeks in Bali with them I got much experiences. From that I knew how to teach English to student. I learned some lesson plans. I learned some activities how to create the materials and the lessons for the different level of students. The second opportunity, I got online learning form U.S. embassy for two weeks. I learned about technology integrated with learning English and teaching English. So I learned the true online learning from teacher all over the world. I learned every day. Maybe ten hours in a week and that was two weeks online learning. It was good for me and it was also free.
\end{abstract}

\title{
5. Discussions
}

Based on the analysis, the researchers discovered that student who was learning to speak in public had three different levels of anxiety. There were trait anxiety, situational-specific anxiety, and state anxiety. It was happend to Boy. Boy had trait anxiety because he was afraid of being the focus of attention. The researchers discovered that the anxiey level that happened to Boy was influenced his confidence to speak English in public. The finding is in line with the previous research by Miskam and Saidalvi (2019) who stated that when students are expected to speak English in front of their peers, they become self-conscious. As a result, when asked to speak English in class, he got nervous. The student's constraints in doing public speaking were the same as the problems he faced when he has to be friend with his mindset.

Furthermore, situational specific anxiety described Boy's anxiety as a result of his lack of preparation. These statements supported (Xiangming, Liu \& Zhang, 2020) stating that their lack of English ability was frequently an impediment to their participation in classroom learning activities. They were also nervous about having to speak English without any preparation. They would feel more at ease with talks in the language class if they were completely prepared in advance, for example, for certain themes. Boy's worry was also related to a lack of preparation. Boy also stated that speaking English with preparation made him feel less nervous and more confident. He also admitted that he was anxious when he had to speak in front of many people. He did not want to be center of attention. However, he also admitted that he was anxious only in front of public. He is afraid if he cannot be good speaker. He gets out from comfort zone. So, in order to speak English in front of a large group of people, he attempts to remain cool and relaxed. Something for sure that he did practice in front of mirror and in his room. He wants to do the best in his public speaking because he wants to have good communication skill that it will be usefull for others. 
Finally, state anxiety was experienced by Boy in learning public speaking since he felt anxious giving an English speech. He was also anxious if he made mistake in public speaking. In addition, he felt anxious due to lack of vocabulary and fear of being center of attention. It means that he experienced a combination of trait and situation-specific anxiety. Meanwhile, dealing with causes of anxiety in speaking English, it was revealed three causes of anxiety. They were communication apprehension, test anxiety, and fear of negative evaluation. This finding is line with Asysyifa, Handayani, and Rizkiani (2019) who claimed that students were nervous about speaking because of a lack of preparation, a fear of falling behind in understanding the material or what the teacher was saying, a fear of making mistakes, a fear of being laughed at by their peers, and a lack of confidence in their ability to spell, pronounce, and select English words.

\section{Conclusions and Suggestion}

The present study has sought to investigate the anxiety level of Indonesian EFL students in a public speaking class. There are two significant points can be attracted as a conclusion. First, there were three kinds of anxiety experienced by the student in learning public speaking namely trait anxiety, situational-specific anxiety, and state anxiety. Second, the anxieties were experienced by the student in learning public speaking such as communication apprehension, test anxiety and fear of negative evaluation. At first, he feels nervous, shy, fear of mispronounced, trembling, blank and afraid being center of attention. While waiting for his turn to do public speaking, student feels uneasy, nervous, and anxious. Not all practices done by student are completed properly. Factors that make student anxious and not confident when speaking in public are fear of being laughed, fear of mispronounced, fear of making mistakes, fear of being center of attention, lack of vocabulary, memorizing but when practice becomes forgotten or blank. The way student does self-control so that he can complete public speaking is to assume all audiences are friends, try to be confident, so that he is calm, change the mindset, practice then relax. The findings of this study show that high levels of anxiety can lead to a variety of outcomes, including a lack of confidence in one's abilities, difficulty speaking in public, minimal conversation participation, failure to initiate conversation, and eventually becoming selfconscious and inhibited speakers. This can lead to increased anxiety, as fear of failure, panic, and the introduction of new information can overwhelm foreign language learners. All of these negative circumstances may impact their attempt to learn English, obstructing their learning and, as a result, causing them to do poorly in their spoken English. As suggested, this research can motivate the teacher to have outside of class to improve students' achievement and motivation because outside of the main class minimize the students' anxiety for optimal output in learing process. In addition, the next researchers are also expected to explore on the same topic so that they can find a better finding.

\section{Acknowledgment}

This paper is based on the first author's thesis in the graduate program of ELT, University of Islam Malang, East Java, Indonesia. Special thanks are addressed to the anonymous reviewers of this journal for their feedback on the earlier version of this paper.

\section{References}

Agar, M. (1980). Getting Better Quality Stuff. Urban Life, Vol 9 No. 1, p. 103

Ahmed, N. F. (2016). An exploration of speaking anxiety with Kurdish university EFL learners. Journal of Education and Practice, 7 (27), 99-106.

Anandari, C. L. (2015). Indonesian EFL students' anxiety in speech production: Possible causes and remedy. TEFLIN Journal, 26 (1), 1-16.

Aripin, N., Noorezam, M., \& Rahmat, N, H. (2020). Kinesics in oral presentation: exploring speaking anxiety through narrative enquiry. European Journal of English Language Teaching, 6 (2), 72-85.

Asysyifa., Handayani, M H., \& Rizkiani, S. (2019). Students' speaking anxiety in EFL classroom. Professional Journal of English Education, 2 (4), 581-587

Atas, M. (2015). The reduction of speaking anxiety in EFL learners through drama techniques. Procedia - Social and Behavioral Sciences, 176, 961-969

Bartholomay, E, M., \& Houlihan, D, D (2016). Public speaking anxiety scale: preliminary psychometric data and scale validation. (pp. 211-215). Elsevier

Brown, D. H. (1994). Principles of language learning and teaching. USA: Prentice Hall. 
Cagatay, S. (2015). Examining EFL students' foreign language speaking anxiety: The case at a Turkish state university. Procedia - Social and Behavioral Sciences, 199, 648-656

Cahyono, B.Y., \& Widiati, U. (2011). The teaching of English as a foreign language in Indonesia. Malang: State University of Malang Press.

Clandinin, D. J., \& Caine, V. (2008). Narrative Inquiry. Lisa M. Given (Ed.), The sage encyclopedia of qualitative research methods. 542-545

Clandinin, D. J., \& Connelly, F. M. (2000). Narrative inquiry. experience and story in qualitative research. San Francisco: Jossey-Bass Publishers.

Creswell, J. W. (2012). Educational research: planning, conducting, and evaluating quantitative and qualitative research. Library of congress cataloging-in-publication data. $4^{\text {th }}$ ed. 140 236.

Dincer, B., Ozcelik, S, K., Ozer, Z., Bahcecik., N. (2020). Breathing therapy and emotional freedom techniques on public speaking anxiety in Turkish nursing students: $A$ Randomized Controlled Study. (pp. 1-8). Elsevier

Felman, A. (2020, January 11). What to know about anxiety. Medical News Today. Retrieved from https://www.medicalnewstoday.com/articles/323454\#what-isanxiety

Gallego, A., McHugh, L., Villatte, M., \& Lappalainen R. (2020). Examining the relationship between public speaking anxiety, distress tolerance and psychological flexibility. (p. 128133). Elsevier

Horwitz, E. K., Horwitz, M. B., \& Cope J. (1986). Foreign language classroom anxiety. The Modern Language Journal, Vol. 70, No. 2 (summer, 1986), 125-132

Irawan, R., Warni, S. \& Wijirahayu, S. (2018). EFL learners' speaking anxiety in an EOP program. Journal of ELT Research: The Academic Journal of Studies in English Language Teaching and Learning, 3 (2), 193-203.

Karatas, H., Alci, B., Bademcioglu, M., \& Ergin, A. (2016). An Investigation into University Students ${ }^{\text {ee }}$ Foreign Language Speaking Anxiety. Procedia - Social behavioral Sciences, 232, 382-388

Kelsen, B. A. (2019). Exploring public speaking anxiety and personal disposition in EFL presentations. Learning and individual differences. 73, (pp. 92-101). Elsevier

Knight, M. L., Johnson, K. G., \& Stewart, F. (2016). Reducing student apprehension of public speaking: evaluating effectiveness of group tutoring practices. Learning Assistance Review, 21 (1), 21-54

Lincoln, Y. S., \& Guba, E. G. (1985). Naturalistic inquiry. Newbury Park, CA: Sage Publications.

Lindner, P., Miloff, A., Fagernas, S., Andersen, J., Sigeman, M., Andersson, G., --- Carlbring, P. (2018). Therapist-led and self-led one-session virtual reality exposure therapy for public speaking anxiety with consumer hardware and software: A randomized controlled trial. Elsevier

Liu, M. (2007). Anxiety in oral english classrooms: a case study in china. Indonesian Journal of English Language Teaching, 3 (1)

Macintyre, P., \& Gardner, R. (1991). Investigating language class anxiety using the focused essay technique. The Modern Language Journal, 75 (3), 296-304

Miskam, N. N., \& Saidalvi, A. (2019). Investigating English language speaking anxiety among malaysian undergraduate learners. Asian Social Science, 15 (1)

Mukminin, A., Masbirorotni., Noprival., Sutarno., Arif, N., \& Maimunah. (2015). EFL speaking anxiety among senior high school students and policy recommendations. Journal of Education and Learning. 9 (3), 217-225.

Omrod, J.E. (2011). Educational Psychology: Developing Learner. Boston: Pearson Education.

Polkinghorne, D. E. (2007). Validity issues in narrative research. University of Southern California, Los Angeles. Qualitative Inquiry. 13 (4), 471-486

Raja, F. (2017). Anxiety level in students of public speaking: causes and remedies. Journal of Education and Educational Development, 4 (1), 94-110.

Santriza. (2018). An analysis of students' anxiety in speaking performance, (A Study at Second Grade at SMAN 5 Banda Aceh). A Thesis.

Suleimenova, Z. (2013). Speaking anxiety in a foreign language classroom in Kazakhstan. Procedia - social and Behavioral Sciences, 93, 1860-1868. Elsevier 
Theophilia, J. A (2018). Students' anxiety in public speaking. Yogyakarta: English Language Education Study Program, Department of Language and Arts Education, Faculty of Teachers Training and Education, Sanata Dharma University.

Woodrow, L. (2006). Anxiety and speaking English as a second language. In: RELC journal, vol. 37 n. 3, p. 308- 328. ISSN 0033-6882.

Xiangming, L., Liu, M., Zhang, C. (2020). Technological impact on language anxiety dynamic. Elsevier 